\title{
USING LANGUAGE CASUAL STYLE IN TEENAGERS 17 YEARS OLD ON INSTAGRAM COMMENT
}

\author{
Indah Apriyani ${ }^{1}$, Suwarsih Asmawati ${ }^{2}$ \\ ${ }^{1}$ IKIP Siliwangi \\ ${ }^{2}$ IKIP Siliwangi \\ ${ }^{1}$ 1indahapriyani06@gmail.com, ${ }^{2}$ suwarsihasmawati@gmail.com
}

\begin{abstract}
This research paper aims to find out of casual style used by teenagers of social media instagram. Instagram comment is always used by teenagers to interact with their friends using casual style. This research used qualitative descriptive method. The object of this research is the casual style used on instagram comment by teenagers. The data are casual style words on instagram comment by teenagers used when interact with their friends. The data source is the post on their account on instagram and the researchers taken 9 post from 3 accounts that used on instagram comment and containing casual style that they were used. In analyzing the data, the researchers classifies the data into types of casual styles based on eggins theory.

Based on analysis the researchers found that from 3 account and 9 post from their post the researchers conclude that there are 51 casual style that used on instagram comment by teenagers and there are 32 declarative types of casual style, there are 3 exclamative types of casual style, there is 7 introgative types of casual style and the last there are 11 harsh words type of casual style. The total of casual style that used on instagram comment by teenagers are 51 and there are 4 types of casual styles in that instagram comment. This means that the more appear of casual style are in declaratives.
\end{abstract}

Keywords: Casual style, Teenagers, Instagram commen

\section{INTRODUCTION}

Sociolinguistics is a study of language which is associated with social conditions. Language is a tool to communiation. According to Dhieni, Fridani, Muis, \& Yarmi, (2014) language is a system of symbols to communicate with other people, including creativity and system rules. Rosdiana et al (2014) Language is an arbitrary sound symbol system used by members social groups to work together, communicate and identify themselves. Language is variety, there kind of language such as Frozen Style, Formal Style, Consultative Style, Casual Style, Intimate Style. In this research focus used Casual Style. Casual Style is the style in which friends and insiders speak.

According to Ridianto (2018) Casual style is a style used in informal (casual) situation and using informal language. There are kind of Casual Style are Declarative, Imperative, WhInterrogative, Polar Interrogative, Exlamation Language to help get information communication. In this era, many people use internet to get information. Internet can connect people to the others by social media. Social media is an online content created using publishing technologies that are highly accessible and scalable. According to Aula (2010) Social media is characterized by interactivity - participants freely send, receive, and process content for use by others. Especially in teenagers they use internet. Accorrding to Batubara (2016) Teenagers is a critical period of transition from children to adults. Stage of adolescent development by 
mappiare in moh ali 2012 classification of teenagers from 12 years old - 22 years old for women, and for men from 12 years old - 21 years old.

internet almost all day long and instagram is the most social media that is loved by all circles, especially by young people. According to $\mathrm{Hu}$, Manikonda, \& Kambhampati (2014) Instagram is a relatively new form of communication where users can easily share their updates by taking photos and tweaking them using filters. They are interact with this social media (instagram) and they always make a conversation on comment to interact with their friends and many peoples use casual style to interact each other. The most on instagram comment using casual style what else in teenagers circle such as : ilysm (i love you so much), ma girl (my girl), thx (thank you). In this research, the writer focuses on sociolinguistics analysis studying about the casual style , casual style is kind of language style. The researchers uses the instagram comment because in this era many people use social media and they think that it makes easier to get information also in instagram is the popular social media in teenagers they always interact and make a conversation in instagram comment. The purpose of this research is to find out the kinds of casual style by teenagers in instagram comment and to describe the meaning of casual style used in instagram comment.

\section{METHOD}

In this research, the researchers used qualitative descriptive method. The researchers would try to analyze the data and make a description about casual style types of language style, and to find out used of casual style on instargram comment by teenagers. According to Mulyadi (2011) A Quantitative research is a research approach that represents the understanding of positivism, while qualitative research is an approach that represents a familiar naturalistic research (phenomenology). The researcher takes qualitative research because this research is to find out the casual style that is used in instagram comment by teenagers. The writer collected the data, which were from social media instagram to get the data, and then analyzed the data. In doing this research, there are some steps used by the researchers in collecting the data. First, the researchers did searching on instagram which one the teenagers that used casual style on their instagram comment. Second the researcher analyzed types of casual style that used by teenagers on instagram comment. Third, the data were tabulated based on the types of casual style.

\section{RESULTS AND DISCUSSION}

\section{Results}

Table of casual style on instagram comment by teenagers 19 years old and classification casual style.

Table A Account 1 - 3

\begin{tabular}{cccc}
\hline No & Account 1 & Account 2 & Account 3 \\
\hline 1 & Classic Italian family & $\begin{array}{c}\text { OMG i } \\
\text { love you so } \\
\text { much }\end{array}$ & I hate the cowboy \\
\hline 2 & $\begin{array}{c}\text { Good looking family, } \\
\text { Happy Easter! }\end{array}$ & $\begin{array}{c}\text { Ma girl is } \\
\text { so hot }\end{array}$ & Really?
\end{tabular}




\begin{tabular}{|c|c|c|c|}
\hline 3 & Beautiful family! & $\begin{array}{c}\text { OMG } \\
\text { you're } \\
\text { gorgeous }\end{array}$ & Love the caption \\
\hline 4 & $\begin{array}{l}\text { Happy birthday, Sorry } \\
\text { it was kinda late }\end{array}$ & $\begin{array}{l}\text { Aw thank } \\
\text { you } \\
\text { ilysmmmm }\end{array}$ & Omg my absolute fans \\
\hline 5 & Bong asshole & & $\begin{array}{c}\mathrm{R} \text { u a giants fan/something } \\
\text { ? }\end{array}$ \\
\hline 6 & When boi & & Bcuz she has no friends \\
\hline 7 & Dope & & What $\mathrm{R} \mathrm{u}$ even doing here \\
\hline 8 & Fresh & & Iam on a boat $\&$ bored \\
\hline 9 & Nerd haha & & You a giants fan \\
\hline 10 & Super Savage ..... jk & & You're so cute \\
\hline 11 & Lets go mets!!!!! & & $\begin{array}{l}\text { This is cute even though u r } \\
\text { a giants fan }\end{array}$ \\
\hline 12 & $\begin{array}{l}\text { Where's our pic lets go } \\
\text { mets }\end{array}$ & & Stoopid \\
\hline 13 & $\begin{array}{c}\text { Hharry potter lookin } \\
\text { ass }\end{array}$ & & So pretty \\
\hline 14 & & & Holly \\
\hline 15 & & & U look so good oh my god \\
\hline 16 & & & Beautiful \\
\hline 17 & & & U look amazing \\
\hline 18 & & & U look perf \\
\hline 19 & & & Damn \\
\hline 20 & & & Yas boo slay \\
\hline 21 & & & Gorgeous \\
\hline 22 & & & Looks so so good!!! \\
\hline 23 & & & Damn slay \\
\hline 24 & & & $\begin{array}{c}\text { When u try your best \& you } \\
\text { don't succeed }\end{array}$ \\
\hline 25 & & & Ughhh wtf \\
\hline 26 & & & Adorable \\
\hline 27 & & & Cute \\
\hline 28 & & & $\begin{array}{l}\text { Such a clever caption } v \\
\text { proud of you }\end{array}$ \\
\hline 28 & & & $\mathrm{~A} \$ \$$ \\
\hline 29 & & & Cool!! \\
\hline 30 & & & $\begin{array}{l}\text { Love how everybody hates } \\
\text { you }\end{array}$ \\
\hline 31 & & & Why 80 ? Why not 21 ? \\
\hline 32 & & & Nope they are bad \\
\hline 33 & & & Nobody wanted you in it \\
\hline 34 & & & That hurt \\
\hline
\end{tabular}

Notes 


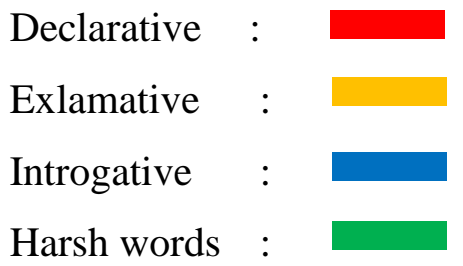

Based on the data above we found that from 3 account and 9 post from their post we conclude that there are 51 casual style that used on comment instagram by teenagers and there are 32 declarative types of casual style , there are 3 exclamative types of casual style, there is 7 introgative types of casual style and the last there are 11 harsh words type of casual style. The total of casual style that used on instagram comment by teenagers are 51 and there are 4 types of casual styles in that instagram comment.

\section{Discussion}

This research discuss about Casual Style. Casual style is gotten by the researchers on instagram comment of teenagers account. Based on the objective in introduction ,the researchers explain (look at table A) the total of used casual style by tennagers on comment instagram there are 51 .

From each account the researchers was find out 4 types of casual style there are : 32 declarative types of casual style, there are 3 exclamative types of casual style, there is 7 introgative types of casual style and the last there are 11 harsh words type of casual style. The total of casual style that used on instagram comment by teenagers are 51 and there are 4 types of casual styles in that comment instagram.

\section{CONCLUSION}

Based on the result of this research, we conclude that using casual style by teenagers on instagram comment there are 51 of casual style that used by teenagers from 3 account and from their 9 post in their accounts and there are 4 types of casual style on their account that are : 32 declarative types of casual style, there are 3 exclamative types of casual style, there is 7 introgative types of casual style and the last there are 11 harsh words type of casual style. The total of casual style that used on instagram comment by teenagers are 51 and there are 4 types of casual styles in that instagram comment.

\section{ACKNOWLEDGMENTS}

Alhamdulillah all gratitude to Allah S.W.T who gave His blessing to researchers, so researchers can finish this article with good health condition. Researchers would like to say thank you to IKIP Siliwangi Bandung and for Aseptiana Parmawati M.Pd which gave us opportunity to publish this article.

\section{REFERENCES}

Aula, P. (2010). Social Media, Reputation Risk And Ambient Publicity Management. Strategy \& Leadership, 38(6), 43-49.

Batubara, J. R. L. (2016). Adolescent Development (Perkembangan Remaja). Sari Pediatri, 12(1), 21-29.

Dhieni, N., Fridani, L., Muis, A., \& Yarmi, G. (2014). Metode Pengembangan Bahasa.

Hu, Y., Manikonda, L., \& Kambhampati, S. (2014). What We Instagram: A First Analysis Of Instagram Photo Content And User Types. In Eighth International Aaai Conference On 
Weblogs And Social Media.

Mulyadi, M. (2011). Penelitian Kuantitatif Dan Kualitatif Serta Pemikiran Dasar Menggabungkannya. Jurnal Studi Komunikasi Dan Media, 15(1), 128-137.

Ridianto, R. (2018). Students'perception On Language Style Used By English Lecturers In The Classroom. Jurnal Basis, 5(1), 39-44.

Rosdiana, Y., Supratmi, N., Izzati, A. N., Mundrati, T. W., Prakoso, T., Setiawati, L., \& Badriyah, R. (2014). Bahasa Dan Sastra Indonesia Di Sd. 